\title{
Dispossession and the Depletion of Social Reproduction
}

\author{
Bina Fernandez \\ School of Social and Political Sciences \\ University of Melbourne \\ Melbourne, Australia \\ bfernandez@unimelb.edu.au
}

\begin{abstract}
Gender is largely under-theorised in the now well-developed literature on dispossession; this paper contributes to the analysis of the gender dimensions of dispossession by bringing the literature on dispossession into conversation with the feminist literature on social reproduction, specifically, depletion of social reproduction. Drawing on qualitative field research, the paper provides a gendered analysis of the multiple vectors of dispossession affecting the Miyana, a Muslim community living in the Little Rann of Kutch, an estuarine zone in central Gujarat within which prawn harvesting and salt production are their symbiotic seasonal livelihood activities. Using the concept of depletion as a diagnostic tool, I argue that the assessment of depletion due to dispossession requires investigation of the levels of mitigation, replenishment or transformation available to individuals, households and communities within the circuits of production and social reproduction.
\end{abstract}

Keywords: gender, dispossession, social reproduction, prawn production, livelihoods, India

The contemporary resurgence of interest in dispossession (Adnan 2013; Banerjee-Guha 2010; Borras et al. 2011; Glassman 2006; Li 2011) has elucidated the multiple modalities through which such processes occur, drawing on and occasionally challenging David Harvey's (2003a) account of contemporary globalisation as generating ongoing processes of "accumulation by dispossession". Yet gender remains under-theorised in the now well-

This is the author manuscript accepted for publication and has undergone full peer review but has not been through the copyediting, typesetting, pagination and proofreading process, which may lead to differences between this version and the Version of Record. Please cite this article as doi: $10.1111 /$ anti.12350

This article is protected by copyright. All rights reserved. 
developed literature on dispossession, and Nancy Hartsock's (2006: 187) observation in her critical review of Harvey that "this round of primitive accumulation is not gender neutral but is built on the backs of women" has gone largely unheeded except for the work of feminist scholars (Casolo and Doshi 2013; Federici 2004; Keating et al. 2010; White and White 2012). This paper contributes to the analysis of the gender dimensions of dispossession by bringing the literature on dispossession into conversation with the feminist literature on social reproduction, specifically the concept of depletion of social reproduction (Rai et al. 2014). The paper uses an empirical case study of the multiple vectors of dispossession that confront the Miyana, a Muslim fisher community dependent on the arid, semi-desert region of the Little Rann of Kutch (LRK) in Gujarat, India for their traditional livelihoods of seasonal prawn harvesting and artisanal salt production. Foregrounding social reproduction as a central axis of analysis, the paper offers a set of theoretical propositions using the concept of depletion (Rai et al. 2014) as a diagnostic tool to assess the gendered consequences of the dispossession faced by the Miyana.

This case study of dispossession of prawn harvesters' livelihoods within the LRK is particularly interesting because of the focus on a fishery resource. Fisheries are a natural resource economy that differ to some extent from the conventional agrarian models of dispossession focused on access to land or forest resources because of the mobility of the resource (fish) and the general absence of private property rights (Sinha 2012). Nevertheless, as Campling and Havice (2014) show in their historical materialist analysis, coastal and estuarine resources can be considered forms of property and therefore sites of social struggle under capitalism, regardless of the juridical interest that holds formal rights. The LRK is a common property resource where, despite the absence of de jure private property rights, de facto occupation and usufructory rights generate violent contestation, as the lucrative returns to prawn harvesting over the past two decades has rendered the region vulnerable to processes of capture and dispossession. Comparable zones of dispossession where new claims are being (often violently) established have been documented in other coastal wetland regions, particularly in the Sunderbans in West Bengal (Jalais 2010), Chilika lake in Orissa (Adduci 2009), Noakhali in Bangladesh (Adnan 2013), and in Ecuador (Veuthey and Gerber 2012). While there is a growing literature offering gendered analyses of estuarine and marine 
resources (Fröcklin et al. 2013; Harper et al. 2013; Hauzer et al. 2013; Ngwenya et al. 2012; Kabir et al. 2011; Pearson et al. 2013), such studies in India are limited. A few Indian studies of fishery resources analyse gendered access to and control over resources and gender divisions of labour (Immanuel and Syda Rao 2009; Jalais 2010; Salim and Geetha 2013; Sharmin and Khan 2011; Shobhana Warrier 2001), however, none focus on the gender dimensions of dispossession.

This paper draws on empirical research undertaken in January 2014, which was a component of a larger multi-sited, qualitative study on rural women's livelihood initiatives in Gujarat, Maharashtra and Tamil Nadu states in India. The larger project aimed to investigate the functioning of the Azaad Machimaar fisherwomen's co-operative (AMC) in Maliya block of Rajkot district in Gujarat, however, it was apparent that the fisherwomen were facing deep processes of dispossession that the co-operative was ill-equipped to counter. The present paper is an exploratory study that emerged from the observation of these processes, and draws on semi-structured, in-depth interviews conducted with 15 key informants including 11 members of the AMC, three representatives of Area Networking and Development Initiatives (ANANDI; a Gujarat based NGO focussed on rural women's empowerment that supported the formation of the AMC) and an officer from the Gujarat fisheries department. Interviews were between 45 minutes to two hours in length; all interviews were conducted with the assistance of a Gujarati interpreter and subsequently transcribed and translated; all participants have been given pseudonyms. Additionally, one focus group discussion was conducted with the board members of the AMC. Interviews with the fisherwomen used participatory methods (including mapping, a pictorial tool-kit and a field walk to the LRK fishing sites) to engage women in a discussion of household ownership of assets, sources of livelihoods, decision-making on income and expenditure, and gendered divisions of labour. The fisherwomen interviewed were all Miyana Muslim, between 35-65 years old, all either illiterate or with only a few years of education. They were all married, with the exception of one widow and one divorcee. The paper triangulates data from these qualitative interviews with secondary data from other government and NGO sources, including a quantitative survey investigating the socio-economic conditions and health status of prawn harvesters in the LRK conducted by ANANDI and the Centre for Enquiry into Health and Allied Themes 
(CEHAT) in 2010 (Pradhan 2011). An important caveat to acknowledge here is that since the scope of this empirical research is relatively limited, the robustness of the conceptual implications suggested by the paper would need to be tested through further research, both in this and in other contexts of dispossession.

The paper proceeds as follows: the next section outlines the key concepts of dispossession, social reproduction, and depletion; discusses the theoretical and empirical work of feminist scholars who examine women's dispossession, and provides the conceptual framing for this paper. The third section describes the livelihood systems of the Miyana, while the fourth discusses the multiple vectors of dispossession they face. In the fifth section, I discuss how the two main property regimes in the LRK articulate with Miyana fisher household livelihood and labour strategies, with differential gendered consequences for dispossession and the depletion of social reproduction. In the conclusion, I draw together the strands of analysis to develop three general propositions that could be used to centre social reproduction in analyses of dispossession.

\section{Theoretical Connections: Women, Dispossession, and Social Reproduction}

The intellectual lineage of both the key terms of this paper, dispossession and social reproduction, can be traced to Marx. Here, I first introduce the concept of dispossession, followed by the concepts of social reproduction and depletion through social reproduction. Next, I review the feminist theoretical literature and empirical studies of women and dispossession; and finally, provide the conceptual framing for this paper.

In the first volume of Capital, Marx (1976) identifies primitive or original accumulation as the historical process of the violent dispossession of producers from their means of production. For Marx, primitive accumulation was a necessary preconditions of capitalist accumulation, but nevertheless distinct from it because it involved the "extraeconomic" methods of conquest, enslavement, fraud, force, murder and theft by which peasants were dispossessed. His analysis was based on the enclosure of the commons in England and the forcible exclusion of particular social groups (peasants, swidden cultivators, hunter-gatherers, fishers, craftsmen) from open access commons resources to which they formerly had access and on which they were dependent for production and subsistence. The 
denial of access to commons resources undermined the capacity of these now dispossessed social groups for self-provisioning, compelling them to sell their labour, which is then deployed in industrial production, thus facilitating capitalist accumulation (Glassman 2006; Harvey 2003a; Levien 2015a). Challenging Marx’s conceptualization of primitive and capitalist modes of accumulation as sequential stages, Rosa Luxemburg (1968) made an early argument that they should be viewed as organically linked and co-existing.

David Harvey's (2003a, 2003b) reformulated concept of "accumulation by dispossession" captures the new unprecedented new ways, through the commoditization and corporatization of formerly "public goods" such as universities, public utilities and entitlements to welfare and national health care (Harvey 2003a: 147-148). Other Marxist scholars identify a range of contemporary mechanisms of dispossession: for instance, important means of rural dispossession Tania Murray Li (2009 :71-72) distinguishes are the closing of the forest frontier for conservation, the seizure of land by the state or state-supported corporations and the dispossession of small-scale farmers as a result of their exposure to global competition from agricultural systems backed by subsidies and preferential tariffs; while Glassman (2006) considers legally enforced debt repayment and the exploitation of unwaged domestic labour in the realm of social reproduction. As Levien (2015a: 148) observes, dispossession has been variously used to refer to: proletarianisation of peasants and formation of a class of agrarian capitalists; a gradual process of class differentiation; to the use of debt as an effective lever of primitive accumulation, and to the diversion of agricultural surplus into industrialization. He proposes the concept of "regimes of dispossession" to illuminate the diverse forms of coercive redistribution and accumulation that serve different class interests at different periods and places (Levien 2015a: 153).

A feminist lens to illuminate theories of dispossession requires bringing to the foreground the inter-relationship between production and social reproduction. Broadly conceived, social reproduction is the labour and set of social processes and relationships that supports production, exchange, and the maintenance of individuals, households and communities. Beginning with Marx's insight that "every social process of production is, at the same time, a process of reproduction" (quoted in Edholm et al. 1978: 107), Marxist feminists in the 1970s emphasised the centrality of social reproduction to capitalism. They 
viewed women's unpaid labour in households as essential to the extraction of surplus value in capitalism, and further, saw patriarchy as intimately articulated with capitalism through patriarchal values upholding the sexual division of labour within households and the workplace (Hartmann 1981; Young et al. 1981).

Social reproduction was further differentiated by Edholm et al. (1978: 104) as "three different 'reproductions' which correspond to different levels of theoretical abstraction", now widely accepted within feminist literature as:

[i] biological reproduction of the next generation of labourers;

[ii] reproduction of labour power or the daily maintenance of individual labourers (through unpaid productive, domestic, subsistence and care labour within the households); and

[iii] reproduction of labour as a social class (the regeneration of the social relations of production and the cultural constitution of the labour force through skills, expertise, values, attitudes, practices and identities).

This categorisation was nuanced by feminists pointing to the significance of geographical, cultural and temporal variations in the social reproduction of households (Molyneux 1985); focussing on women's (paid and unpaid) work at other sites of social reproduction such as schools and nursing homes (Kofman 2010), identifying the psychological and ideological dimensions of social reproduction and analysing the role of the state and market forces in contributing to social reproduction through welfare provisioning (Bakker and Gill 2003).

Drawing on Diane Elson's (1998) conceptual framework of these multiple dimensions of social reproduction, Rai et al. develop the concept of depletion which they define as "the level at which the resource outflows exceed resource inflows in carrying out social reproductive work over a threshold of sustainability, making it harmful for those engaged in this unvalued work" (2014: 88-89). Resource outflows could include unpaid domestic, subsistence, caring and voluntary community labour, while replenishing resource inflows could include health care, welfare provisioning and community support networks. A negative balance between the outflow and inflow is damaging for the health and well-being of 
individuals, households and communities (at varied rates in different contexts). My approach in this paper is to use the concept of depletion to analyse the gendered consequences of dispossession for social reproduction, an approach that builds on and extends the feminist scholarship on dispossession.

Feminist scholars critique Marx and Marxists for failing to recognize the centrality of social reproduction to accounts of dispossession. In an early analysis that went against the grain of extant economic history, Jane Humphries (1990) documents archival evidence of the importance of women's subsistence livelihoods from the commons to peasant households in late Eighteenth century England. Her gendered reading demonstrates significant consequences for peasant women of dispossession from the commons due to enclosures: the elimination of women's nonwage, subsistence sources of survival, their increased dependence on male wages and wage-earners, and their availability for wage employment if and when they were needed. Also critiquing Marx, Maria Mies (1986) offered an early, powerful analysis of how the expropriation of women's social reproductive labour is an ongoing form of primitive accumulation that is a foundation of capitalism. In a similar vein, radical Marxist feminist Silvia Federici $(2004,2010)$ asserts that primitive accumulation was historically contingent on the violent disciplining of women through witch hunts and the expropriation of their reproductive labour. Nancy Hartsock (2006: 182-187) goes further in her insightful evaluation of Harvey's lack of attention to gender, arguing that the "feminization of primitive accumulation" in the contemporary moment of globalization is driven by four inter-related processes: the breakdown of the previous social contract and the re-negotiation of social relations; second, the rise of new ideological formations; third the increase in inequalities globally, and fourth the transformation of relations of social reproduction.

There are few empirical gendered analyses of dispossession, and this scholarship often does not explicitly theorise the consequences of dispossession on social reproduction, focussing instead on the gendered violence that accompanies it (see for instance Meertens and Stoller 2001). Levien's (2015b) recent comparative review of five historical and contemporary case studies of gender and land dispossession offers useful insights into diversity in the patterns of inequality and disadvantage as gender intersects with other inequalities such as class, caste and ethnicity. The case studies include research on the 
enclosure of the commons in England, displacement due to state sponsored development projects in India (Bisht 2009; Mehta and Srinivasan 2000; Thukral 1996) and the Gambia, a case study of gendered dispossession due to palm oil plantations in India (White and White 2012), and Levien's own study of dispossession due to the establishment of an industrial Special Economic Zone in India. Levien observes the consequences of dispossession were occasionally ambivalent or positive; in some instances, resettlement offered new employment and educational opportunities for women, and a reduction in domestic burdens. In Levien's assessment however, the dominant experience across the case studies was that women had no say in decision making over resettlement and rehabilitation, they lost access to the commons which affected their subsistence and survival, they often experienced an increase in male alcoholism and domestic violence, and often became trapped in the double bind of state and household patriarchy. Variations were observed primarily in the consequences for the gender division of labour, which Levien (2015b: 127-129) notes should be at the core of debates on land dispossession; an observation that has informed this paper.

Drawing from the preceding discussion, the conceptual framing for this paper will use Li's (2009) articulation of three vectors of rural dispossession mentioned above to analyse the dispossession faced by the Miyana, and additionally, will foreground the gendered relationship between production and social reproduction. Recalling that for Marx, dispossession resulted in "two transformations, whereby the social means of subsistence and production are turned into capital, and the immediate producers are turned into wagelabourers" (quoted in Levien 2015a: 147) (in other words, the commodification of land and labour), I argue there is a third, important but invisible, gendered dynamic of dispossession in which social reproductive labour becomes seemingly excluded from the now commodified circuits of exchange value. This exclusion has important, context dependent implications for all three forms of social reproduction: biological reproduction, the reproduction of labour power, and the reproduction of labour as a social class. A significant effect long noted by feminists is that it allows capitalist production to be subsidized by women's ongoing, unpaid, ostensibly "unproductive" social reproductive labour (Boserup 1970: 28; Mies 1986). To identify the gendered consequences of dispossession faced by the Miyana, this paper draws on Edholm et al.'s (1978) conceptualization of three types of social reproduction to examine 
the gendered dynamics of access to productive resources and division of labour in fisher households. I will then use the concept of depletion (Rai, Hoskyns and Thomas 2014) to analyse the flows of resources within fisher households under conditions of dispossession.

\section{Livelihoods of the Miyana in the Little Rann of Kutch}

This section briefly introduces the Miyana and their livelihoods within the ecological context of the LRK, followed by a discussion of the three main vectors of rural dispossession they confront. The total population of the Miyana in India is estimated at 67,000, 97 per cent of whom live in Kutch and Saurashtra in Gujarat. Their traditional livelihoods are fishing and artisanal salt production; some have small land holdings that allow rain-fed agriculture. The community's self-identification as Rajput Muslim implies a distancing from the historical classification of the Miyana by the British colonial administration (under the Criminal Tribes Act of 1871) as a "Notified Tribe', a nomadic group considered to be "criminal by birth" (Pradhan 2011). When the Indian government repealed the Criminal Tribes Act in 1952, groups such as the Miyana became "de-notified'; however, the Act was replaced by the Habitual Offenders Act, which despite an ostensible focus on individuals, continues to stigmatize and marginalize these groups (Bokil 2002; D’Souza 1999).

A large number of the Miyana live in Maliya block, Rajkot district, where Muslims constitute 22 percent of the population in contrast to nine percent of the total population of Gujarat in 2001 (Government of India 2001: 820). As data from the District Census Handbook (Government of India 2001) show, Maliya is one of the most underdeveloped blocks of Rajkot district, one of the most industrialised and developed districts of Gujarat. Maliya is situated to the south of the LRK, a semi-arid, estuarine desert region that is officially a Wild Ass Sanctuary protecting around 2,500 Asiatic wild asses. The LRK faces severe problems of desertification due to recurrent cycles of drought and cyclones, which have led to the erosion of green cover, shortage of sweet water, and problems of increased salinity. Despite these problems, field interviews revealed the region is an important source of local livelihoods based on prawn harvesting and salt production. During a walk around the fishing sites, fisher women described how, for four months during and after the monsoon (July to October), when the salty sea water mixes with rain water, the low depth area of the 
LRK provides an ideal environment for prawn breeding, and thus a low-cost prawn harvesting opportunity. In the eight months after the prawn harvesting season, in a delicate symbiotic balance, the same land is then used by agariyas or artisanal salt producers (many of whom are also Miyana) to generate their livelihoods.

According to local estimates, currently around 3,000 families are engaged in prawn harvesting, operating from 12 base villages along the southern borders of the LRK. ${ }^{1}$ The growth of the number of families involved in prawn harvesting has been a phenomenon particularly of the last two decades. However, it is not only the residents of the 12 base villages on the LRK shore who have staked claims to harvest prawns in these settlements. Since the 1990s, the expansion of lucrative prawn export markets in the ports of Veraval, Porbandar and Mangrol in Gujarat have attracted increasing numbers of people from neighbouring villages, many of whom were not traditionally engaged in prawn harvesting or even fishing. Seasonal prawn harvesters come from much further afield too, from the neighbouring towns and cities of Dhangadhra, Surendranagar, Rajkot, Morbi and Vankaner.

Interviewees described how, during the fishing season, the entire fisher family (including children) leaves their base village and lives in makeshift camps at vandhs or temporary settlements along the shore of the LRK. There are around 40 temporary settlements, none of which appear on local maps. These settlements are located 0.5 to $5 \mathrm{~km}$ away from any main road, on flat plains on the shores of the LRK. This terrain of vast, unmarked mudflats is difficult to negotiate, as there is a constant fear of getting lost. The settlements have absolutely no infrastructure, are lacking in basic amenities such as roads, electricity and drinking water, let alone schools or health centres. The seasonal character of the settlements has rendered them invisible to local government authorities; however, they are crucial for the livelihoods of the families who live and work there. The majority of fisher families derive incomes from prawn harvesting only during the four-month season; only 30 per cent of fisher families continue to earn incomes from fishing during the entire year. Most fisher households also labour in a diverse portfolio of livelihood activities, including

1

according to the District Census Handbook, the total number of fishers in Rajkot in 1998/99 was 2,148 (Government of India 2001) 
agriculture, salt production, daily wage labour, the collection and sale of firewood, quiltmaking, and micro-businesses.

Two types of fishing rights regimes operate in the LRK: open access and common property regimes. ${ }^{2}$ Under an open access regime, no one has the legal right to exclude other persons from using the resource (Ostrom 1999). Open access fishing in the LRK is undertaken by pagadiyas, fishermen who wade in the shallow waters of the LRK by foot, and use katar (nets) and conical bag shaped nets called gunja, which are placed in creeks and rivulets with the mouth placed against the water current. Other open access fishers use flatbottomed boats to ply further out into the waters of the LRK. Nominally, these open access fishers are supposed to obtain licenses from the Fisheries department, however, this is not a requirement that is actively enforced.

Natural resources in common property regimes are owned and controlled by a defined group of people for the benefit of that group; members have an assemblage of rules, regulations, rights and responsibilities established for resource usage and can exclude nonmembers (Ostrom 1999; Pearce and Turner 1990). In the LRK, rights over a dhori (prime prawn harvesting areas) are based on a common property regime. Fisher families with established traditional "haq" or usufructory rights claims to a dhori will go every year to the same area, irrespective of the distance from their base village. These rights are based on de facto usufructory practices, rather than clearly specified formal legal entitlements. Formal de jure entitlements to set up nets for prawn harvesting at the dhoris along the LRK are impossible as the area is within the Sanctuary for Wild Asses.

Salt production is the second key livelihood activity in the LRK. According to the Agariya Heet Rakshak Manch, ${ }^{3}$ Gujarat produces 77 per cent of the total salt consumed in India, and approximately 60 per cent of this is produced by approximately 43,000 artisanal

2

$\square$ Differentiated access to fish resources can be regulated through four types of property regimes: open access, common property, private property or state property, or some combination of the above (Baskaran and Anderson 2005).

3

Translation: Agariya Welfare Forum (http://saltpanworker.blogspot.com/). 
salt producers (agariyas) who live in over 100 villages on the periphery of the LRK. The agariyas are primarily from de-notified communities (Miyanas, Sandhis and Kolis), along with some scheduled castes, scheduled tribes and other backward castes. Salt production is a traditional occupation for the majority of agariyas. They migrate seasonally to the LRK and set up makeshift camps from October to May, paying the Forest Department for a seasonal license to lease 10 acres of LRK land for salt production. As salt production is the traditional occupation of agariyas, they are exempt from paying royalties or cess on salt produced from their lease. In the leased areas, they construct small earthen bunds to form the salt pans; these bunds dissolve with the onset of the monsoon, making way for the prawn harvesters. Salt production entails hard work in harsh desert conditions, yet the agariyas receive very low returns for their labour - making between 12-15 paisa per $\mathrm{kg}$ of salt.

The majority of Miyana are thus "footloose labour" (Breman 2009), engaged as prawn harvesters and salt producers in household based livelihood strategies of "coping migration" for survival (Deshingkar and Farrington 2009). They travel short distances, usually with their whole families for the fishing and salt seasons. Their living and working conditions are extremely onerous and unhealthy. The majority of their earnings are spent at the destinations on food, healthcare and recreation, with limited savings once the season is over. Yet even these meagre livelihoods are threatened by dispossession on multiple fronts.

\section{Multiple Dispossessions}

This paper will show how the Miyana confront both "extra-economic" and capitalist forms of dispossession, through all three vectors of rural dispossession identified by $\mathrm{Li}$ (2010: 72-73): the first vector is the closure of the natural resource frontier through the constitution of the Wild Ass Sanctuary; the second is through the state-supported encroachment by large salt companies that are displacing the livelihoods of both artisanal salt producers and prawn harvesters; while the third vector of dispossession is through the exploitation of prawn harvesters at the tail end of a lucrative prawn exporting industry.

Since the declaration of the LRK as a Wild Ass Sanctuary in 1973, the Forest Department has taken the view that salt making activity has an adverse effect on the wild ass and other wild life in LRK, however action on this official position was only initiated during 
the neoliberal era, in 1997, when the District Collector issued a notification that any claims to traditional usufructory rights had to be made within 60 days. In response, agariyas made representations to the Gujarat state tribal department for recognition of their traditional usufructory rights under the Forest Rights Act, which is pending resolution. Nevertheless, in April 2014 the Gujarat government issued eviction notices to 1,400 agariyas in the LRK (Agariya Heet Rakshak Manch 2014). However, these eviction notices issued to the agariyas cannot simply be viewed as the Gujarat government's effort to support wildlife conservation. In contrast to the small scale, low impact artisanal salt production undertaken by agariyas, large tracts of LRK land have been allocated on long-term leases to four large salt companies in Maliya. The salt companies reportedly obtained their leases through political connections and by paying bribes to the Forest Department, and have encroached on areas beyond their lease. These companies are forcing artisanal salt producers out of business: five years ago there were around 250-300 agariyas operating in the Maliya area, the numbers have now reduced to less than $100 .^{4}$ Additionally, the companies are also a threat to the livelihoods of the prawn harvesters as they have brought in heavy earth-lifting machinery to create bunds that are 10 to 12 feet high. These bunds do not dissolve during the monsoons, and therefore obstruct prawn harvesting. The fisher communities have lodged complaints against the salt companies to the District Collector, the fisheries department, and the Forest Department; none of which had yielded results (in January 2014). The LRK is being subjected by the Gujarat government to the same state-enforced seizure of the commons effected on "gauchar" (pastoral) land belonging to villages that was declared acquirable for industrial purposes. ${ }^{5}$ The state's complicity in this dispossession is made easier by the fact that the LRK was historically considered wasteland and had never been surveyed; consequently, there are no records of land ownership and usufructory entitlements. The declaration of the LRK as a

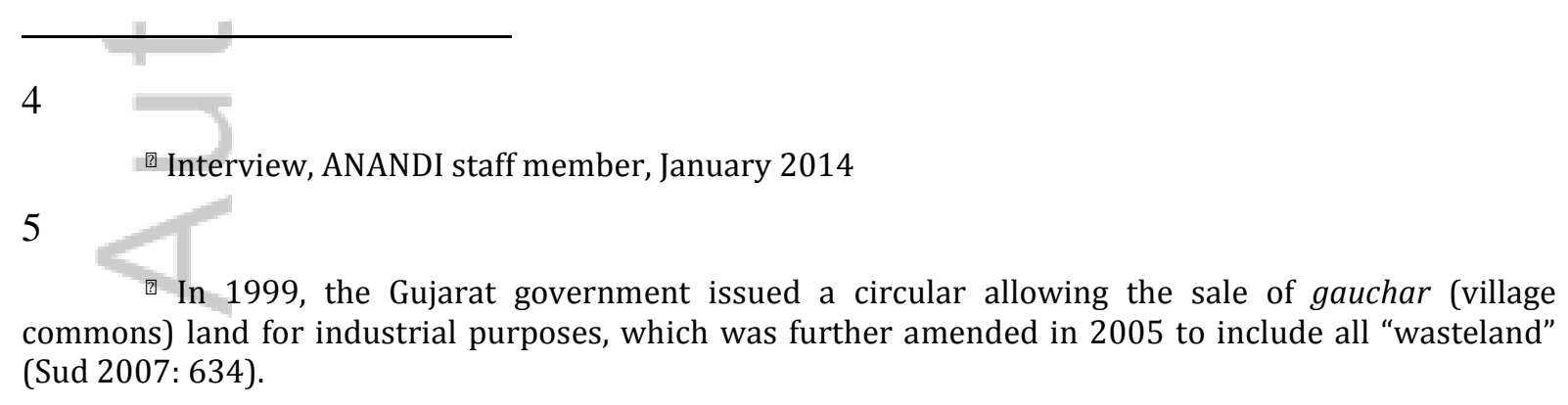


Wild Ass Sanctuary brought the land officially within the control of the Forest Department, but as the LRK is officially wasteland not forest land, prawn harvesters and agariyas are technically ineligible to claim the traditional usufructory rights that forest dwellers are entitled to under the provisions of the Forest Rights Act of 2006. Although wildlife and nature conservation practice could be considered protection of the commons by taking it out of the market, recent scholarship on the reality of conservation practice demonstrates how degradation narratives are deployed to restrict resident populations from access to local natural resource use, while more powerful actors (state, corporate and transnational) appropriate the benefits from such resources (Benjaminsen and Bryceson 2012; Kelly 2011). The third vector of dispossession faced by Miyana fishers is due to their exposure to violence and processes of exploitation within the prawn industry. The "blue revolution" or the massive expansion of prawn harvesting through capture and aquaculture fisheries in many parts of Asia and Latin America (Goss et al. 2000; Lebel et al. 2008) stimulated the Gujarat government's interest in the lucrative earnings from prawn exports. The consequent rapid expansion of prawn harvesting in the 1990s, and as noted previously, the influx of people (many of whom were not traditionally fishers) to the LRK during the prawn harvesting season led to increased pressure on, and violent conflicts over claims to the dhoris. Several interviewees recounted the prevalence of such violent conflicts with outsiders, and the gradual dispossession of local pagadiya fishers' fishing access. For instance, Salim bhai, a former fisher observed: "Some notorious people of this area are gundas [thugs]; about 50-60 such people have come in. The fishermen are poor and they cannot fight for their children; much bloodshed has happened before this." Similarly, Aminaben, whose husband and son were pagadiya fishers recounted how the claims by outsiders to dhori sites resulted in violence: "Now, many have come [to fish] from other villages. They reserved the space [dhori]. If they are not there and we fish, then there will be a fight ... If a fight happens, then we hit one another with sticks. Some might say 'don't fight'. But it tends to happen more among our Muslims." These violent encounters were not only with outsiders, they were also intra-ethnic, and in some cases even involved family members, as Mohsinbhai, a fisherman observed: "It is like this: some may get less, but those who are tough people, they get more. It is like that. This is ours; that is ours, now fighting happens ... I am talking about Musa, my 
nephew. He killed his own uncle." This violent conflict in the LRK is similar to the processes of violent capture and dispossession observed in other prawn harvesting zones globally (Adnan 2013; Benjaminsen and Bryceson 2012; Veuthey and Gerber 2012).

Interviewees recounted how fishers in the LRK also face exploitation at the hands of the local agents who are the intermediaries connecting fishers to the prawn export processing companies in the port cities of Gujarat. These agents who control the local prawn economy in the LRK are not outsiders, they are from five or six Miyana families based in Maliya Miyana (the town that is the headquarters of Miyana block) and the village of Juna Hajiyasar. These agents were among those who had traditional usufructory rights over a dhori site and were able to leverage the higher income from their prawn harvests into investments in transport and storage facilities, which in turn facilitated their role as intermediaries linked to commercial export processing companies.

Agents exercise several strategies of exploitation, chief among which is a cash advance which they offer to fishers at the start of the season for living expenses and/or the hiring of nets and boats. The survey conducted by CEHAT and ANANDI indicated that 63 per cent (nearly two-thirds) of fisher households had taken such loans ranging from Rs.1,000 to Rs.50,000; the percentage was higher for the poorest households, 78 per cent of whom took loans (Pradhan 2011: 43). Subsequently, fishers are forced to sell their catch exclusively to the agent, at prices below the prevailing market rate. As agents set up shop at the settlements, they are aware of the catch size as soon as it has landed, and fishers have limited (if any) opportunities to evade this contract. Nor are fishers likely to even try to evade the contract, as they lack the resources to transport, refrigerate and sell the prawns themselves. The future continuity of their livelihood is dependent on maintaining a relationship with the agent, regardless of how extractive it is. That this relationship is with kin does not make it less extractive, rather, it makes it next to impossible for fisher families indebted to agents to openly resist or oppose them.

According to interviewees, agents stand to gain further from the use of several other exploitative strategies. First, even after deduction of the loan amount from the value of the catch, agents frequently delay payments, making end of season payments. Another strategy is the use of the dibba (recycled oil tins) to calculate the price of prawns. Prices are set per 
dibba, however, dibbas do not conform to standard weights or volumes, ranging from 10-15 $\mathrm{kg}$, which agents manipulate to the disadvantage of the fishers. Agents benefit when the prawns are then sold by weight to the export processing factories in Veraval, Porbandar or Mangrol. At the factories, it is not just the weight, but the "count" or the number of prawns per kg that is important - the lower the "count", the larger the prawn, and the higher the price per $\mathrm{kg}$. Thus, the fishers lose out again, since they do not grade their catch into small and large prawns, they get an average rate that does not necessarily reflect the quality and value of the prawns. Agents pay Rs.250-300 per dibba, but obtain prices up to Rs.50 per kg at the export processing factories. The factories may earn double that, or up to seven times the value of what fishers get.

The exploitative relationship between the agent and poor fishers bears the features of "neo-bondage" in which (fish) prices are not set by the market, debt is used as an instrument of coercive dispossession and the state of bondage continues even after the debt has been paid off, but there are none of the elements of patronage or social security found in traditional bondage (Breman et al. 2009). The key difference from typical "neo-bondage" is that it is not the fishers' wage labour that is tied, but the output of their household production (the prawn harvest) that is tied. In this respect, the tied prawn harvest is similar to the the tied agricultural harvests in Andhra Pradesh analysed by Da Corta and Venkateshwarlu (1999) where farmers take cash advances, and in return, are forced to sell the crop to agents at below market prices. The exploitation of smallholder production in such cases is preferable to wage labour as it is "more profitable for capitalists to appropriate surpluses indirectly through these tied harvest exchange relations (for example, marketing produce and credit) than through production relations based on hiring in labour" (Da Corta and Venkateshwarlu 1999: 89). The agents benefit from the fisher families' self-exploitation of labour; further, tied prawn harvests guarantee the agents' supply of cheap prawns and enables them to counter the threat of new local trader entrants, or even of larger, non-local competitors who come during the season from the port towns and offer higher prices.

The preceding account demonstrated how fisher households confront dispossession through enclosures and encroachment on their access to the LRK fishing sites. It also shows how, as small-scale household producers, the Miyana are linked to local agents through 
exploitative neo-bondage relationships that are pauperising for the former but from which they are unable to withdraw without becoming destitute; the advantage for the agents is this allows them to keep costs down and avoid the countervailing organizational potential of hired wage labour. To make visible the gendered dynamics of this dispossession, the next section undertakes a closer examination of the processes of production and social reproduction within fisher households.

\section{Gendered Consequences of Dispossession}

The gendered consequences of dispossession are analysed through scrutiny of the gendered division of household labour and intra-household access to productive resources. I argue here that the two forms of property regimes identified previously (open access and common property) articulate with Miyana livelihood and labour strategies to produce class differentiation between "Survival" and "Accumulation" fisher households. I then outline the implications for the consequent depletion in fisher households of all three forms of social reproduction: biological reproduction, the reproduction of labour power, and the reproduction of labour as a social class.

Interview data revealed two broad livelihood strategies that correspond to the typology identified by Davis (1996) of survival and accumulation, which can be respectively mapped on to the open access and common property regimes. In mapping the two broad sets of categories in this way I acknowledge that they exist on a graded continuum, and that there are households that occupy intermediate positions; however, the categories are useful contrasting "ideal types" that exemplify the characteristics of these two types of households, differentiating between them with respect to gendered access to productive resources and divisions of labour.

The majority of Miyana fisher households are deeply impoverished, ${ }^{6}$ and are engaged in survival livelihood strategies within which fishing is aimed at subsistence diversification (food security, labour buffering, coping, cash and reciprocal exchange). Their access to the

6 Over 85 per cent of the households surveyed by ANANDI and CEHAT had monthly per capita incomes that were below the poverty line of Rs.502 (Pradhan 2011). 
LRK fisheries is through the open access pagadiya regime, which is subject to overcrowding and overfishing, and the value of their catch tends to be relatively small. Seven of the women interviewed were from this type of household. Depending on the season, other income sources for such households were agricultural labour, salt-pan labour, fire wood collection for sale and quilt making. Households with survival livelihood strategies had limited access to productive resources. They were landless, or had marginal holdings of low quality land. Some households had small livestock that supplemented their subsistence needs. They did not tend to own fishing equipment such as boats, nets and gunjo, and would either rent or take credit advances from agents for equipment during the season.

Within fishing, the productive capacity of Miyana households with survival strategies is contingent on four types of labour: fishing, processing of fish, sale of fish, and the daily reproductive labour of maintaining fisher households at the temporary fishing settlements. Usually men and boys fish (only two of the women interviewed currently fished, although others mentioned fishing when they were younger), while women primarily undertake the other three activities. Once the catch is landed in the morning, women's labour is focused on the processing and sale of the prawns. The women usually sell the fresh catch to agents, though here men may occasionally step in to bargain or negotiate price. When quantity of the catch or the size of the prawn is small, some women will take the catch to sell in the local market in Maliya Miyana as this would fetch a better return than selling to the agents. Women from the poorest households are often primarily involved in trading small value catch. For instance, Aliyaben's husband and two adult sons fished as pagadiyas. She said:

One needs to make huts and stay at the vandh, sister, one needs to stay there. If we have enough nets, then we can go with our sons and stay there. We can earn more. As we don't have equipment, what could we do by going there?

They had limited equipment and a low-value catch; the family therefore did not make camp at the settlement. Aliyaben would sell the fish they caught, and also buy from other fishers to 
sell in the local Maliya market.

At the temporary settlements, women and children are involved in the highly labour intensive fish processing activities of sorting, peeling, boiling, chopping, and drying prawns. Women boil the prawns in large vessels, and then sun-dry them. The monsoon rains, and the lack of dry shelter at the settlements make both boiling and drying prawns extremely difficult, generating acute stress and anxiety amongst the women, as Mominaben observes:

If the stock is about to lose freshness some women may sell it at lower prices ... If we dry it here and it rains, everything will get wet. Then where shall we dry it? We face problems in the monsoon. So it's good if we can sell it fresh ... Much of our stock rots during the monsoon. Once, the rain didn't stop for eight days. We used papers but how could we dry it? It rots and even gets destroyed by insects. We have to take a rickshaw to go throw [the rotten stock] and all our labour would be wasted ...

During the monsoon, if we keep the stock in our homes, the children may fall ill. It would have a foul smell. So we sleep on the floor and keep the prawns on these cots and cover it with paper ... If the fresh stock gets dry then we can keep it for 12 months and it still won't rot. That much labour is there in prawn processing.

In addition to women's role in productive labour in the processing and sale of fish, they are primarily responsible for the arduous social reproductive labour of maintaining households at the temporary settlements. The complete absence of facilities at the temporary settlements means additional hard labour to meet minimal daily survival needs, such as water and fuel. The CEHAT and ANANDI study found that only one of the 13 temporary settlements surveyed had access to piped drinking water facilities (Pradhan 2011: 27). Over half the residents at other settlements are dependent on untreated pond water for drinking, boiling prawns; this water source is shared by cattle. Once this water source dries up, women's labour increases, as water often has to be fetched from villages up to $2 \mathrm{~km}$ away. If the water source is further away, it is purchased from water vendors who fetch it on motorbikes or bicycles. Households spent about 15 per cent of their median income on the purchase of drinking water, a burden that was heaviest for the poorest households. Similarly, the 
collection of firewood for fuel and for boiling prawns is arduous subsistence labour typically undertaken by women and girls. Only a quarter of households buy firewood, 75 per cent collect it from the surrounding area; the percentage is higher for the poorest households, 90 per cent of which collect firewood (Pradhan 2011: 35). Further, women have to cope with the higher burden of health care, as access to health care facilities from the settlements is between 5 and $60 \mathrm{~km}$ away, and the study documents that even when these facilities are accessed, the quality of care is low. It is evident then that women and girls shoulder a disproportionate share of the additional burden of social reproduction of fisher households at the temporary settlements - whether it is to meet daily survival needs or health care of family members.

The poor hygiene and sanitation at the settlements also jeopardised the biological reproduction of these families. The consumption of contaminated drinking water and prolonged exposure to saline water, smoke, heat and prawns led to high morbidity in the population, major reproductive health problems (particularly for women) and skin diseases (Pradhan 2011: 53-77).

The second type of prawn harvester household is characterised by access to the common property regime governed by "haq" or rights to the dhori (prime prawn harvesting areas), which was usually key to the Accumulative livelihood strategy of these households. The means by which they obtained access to the dhori was varied: some obtained access legitimately, either through "traditional" inheritance, or by renting access from the traditional owner, while a few illegitimately captured access through violence. Access to the higher income stream from the dhori enabled these few families to establish their economic dominance by expanding the scale of their operations, and diversifying productive assets and income streams: they owned five or more bighas of land, had livestock, had household members who were engaged in other micro-businesses such as small shops, rickshaw or tempo driving (for the transport of fish during the season, for other goods the rest of the year), mandap (tents for weddings or other events) businesses or "brokering" services. Additionally, ownership of desirable assets such as mechanised boats, cold storage boxes and motor vehicles useful for transporting the catch (motor bikes, trucks, autos) is strongly corelated with these households with higher economic status (Pradhan 2011: 45). Regular 
salaried employment as a village level government or NGO employee was another important "buffer" income stream for households with accumulative livelihood strategies. Unsurprisingly though, there were gender differences in the ownership of assets within households - land and fishing assets (boats and nets) were owned by men within households. Interviewees stated that Miyana women do not "traditionally" own land or houses, it was in the name of their husband or father-in-law; however, a few women did own livestock (goats and chicken) in their names.

It is worth noting however, that not all families with access to a dhori were necessarily able to leverage this access into accumulative livelihood strategies, as the value of the dhori was contingent on the size of family and its access to other productive resources such as land and formal institutional credit. Rokeyaben for instance was an older woman from a household whose members had been fishers for at least 4 generations. Her husband shared a "haq" with his brother, and they took it in turns to harvest prawns from their dhori. Rokeyaben had nine adult, married sons, each with children, who lived in separate households in the same large compound. The divided family "haq" could not support all the households of Rokeyaben's nine sons, and the younger sons are no longer fishers. Only her eldest two sons help her husband fish when it is their turn to harvest, but the sub-division of the catch reduces its value to the finances of the multiple households sustained by it. Rokeyaben's family resolutely avoided falling into the coercive credit trap of the agents, as she said: "We don't take credit and our sons also don't take. These are tough people and if we cannot repay the money, they run to kill us. We don't want that." ${ }^{8}$ However, their lack of agricultural land meant they were unable to access formal institutional credit to expand their fishing enterprise.

In contrast to Rokeyaben, although Mominaben's household did not have a traditional "haq", they had recently obtained access to the dhori by paying rent of Rs.30,000 per anum to the dhori "owner". Some members of her family harvested prawn in the dhori, while others continue to fish in the open waters of the LRK, and one of her sons worked with his father-in-

8

Interview, Rokeyaben, January 2014.

This article is protected by copyright. All rights reserved. 
law in a neighbouring village:

See this daughter-in-law who is sitting there, they go to Tikar ... They are from Venasar and her father has haq in Tikar. So the boat and nets will be her father's and my son goes as partner and he gets one-third part [of the catch]. ${ }^{9}$

While direct access to a haq through ownership, renting, or in partnership with kin offered these households comparatively good opportunities for earning income, the agents" households were able to exceed this. Mominaben's household was renting the dhori from the Shaikhs, the primary family of agents in Juna Hajiyasar. This family had nine brothers, and rather than sub-divide the haq, they found it more lucrative to rent it out to several families. They had diversified and scaled up their investments, giving fishers equipment on credit, and undertaking local purchase, storage and transport of fish to the prawn export processing factories. Importantly, this family is politically well connected, and they are involved with the salt companies too.

The distribution of labour within households with accumulative livelihood strategies allowed for some waged labour to be bought - particularly for processing the prawns (boiling, peeling and chopping), and for agriculture. For some households, this meant older women in particular could reduce or withdraw their labour from the temporary settlements. Thus for instance, Rokeyaben said that because she had a knee injury "I can't chop [the prawns], so we call a girl and give her Rs. 50 (per day]. She chops for us ... The women standing here are three sisters. If we give them some money, they chop". ${ }^{10}$ A couple of the more enterprising among these women would then deploy their labour in selling prawns directly to city markets in Ahmedabad, bypassing the chain of local agents linked to commercial prawn factories in Veraval and Mangrol.

9

Interview, Mominaben, January 2014. 10

Interview Rokeyaben, January 2014. 
Drawing from the discussion above, the following observations are worth noting about production and social reproduction within prawn harvester households. First, this section demonstrated women's significant contributions to co-operative family labour in prawn production and the daily social reproduction of labour power at temporary settlements, both of which are essential to the productivity, survival and reproduction of fisher households, particularly those engaged in survival livelihood strategies. This labour is beyond the "normal" unpaid domestic labour (which women and girls continue to undertake), and should be considered a hidden cost of prawn production that is borne by fisher households. The provision of basic amenities at settlements (through state, community or corporate provisioning) could potentially reduce women's burden of social reproduction. In the absence of such amenities, the labour of women in social reproduction particularly at the temporary settlement is an invisible gendered constitutive component of dispossession faced by prawn harvester households.

Second, a consequence of ongoing dispossession for the social reproduction of fisher households as a class is the intensification of class differentiation. A minority of Miyana fisher households with accumulative livelihood strategies have used their (sometimes forcibly acquired) access to productive resources to leverage investment and expansion; further, they achieved control over the local prawn economy through strategies of co-ethnic exploitation. The class differentiation due to dispossession in the LRK has a gender aspect, as women from both the poorest and from better off households withdraw their labour from prawn processing and from social reproductive labour at the temporary settlements. The former withdraw because of the pauperising effects of dispossession, while the latter withdraw as a form of gendered status reproduction, since their labour can now be bought in.

Third, I argue that fisher households with survival livelihood strategies are experiencing depletion in social reproduction induced by the multiple vectors of dispossession described above. That is, these households are below the threshold of sustainability at which resource outflows from the household exceed the inflows for social reproductive work, with harmful consequences for the (primarily) women engaged in this work. Increasingly, their income from fishing fails to adequately compensate the labour of all the household members involved in the process, with the consequent depletion of the 
household's capacity for all three forms of social reproduction. Evidence of this depletion is most immediately obvious in the documented poor health and well-being of fishers, including women's reproductive health and their capacity for biological reproduction. The depletion of the household's capacity to reproduce labour power is evident in its inability to sustain reinvestment in maintaining the means of production (boats and nets) or expand the enterprise from the surplus generated from fishing. Marks (2012) observes similar trends in his longitudinal study of Louisiana shrimp fisher families. Finally, the reproduction of the Miyana fisher household as a class has become increasingly precarious, as it faces the depletion of community and kinship bonds, due to intra-ethnic violence and extractive relationships. Dispossession proletarianises the poorest households, forcing members to become increasingly dependent on other waged labour to supplement and stabilise the uncertain income from fishing. As the next generation abandons fishing, the loss of cultural knowledge and practices of the fishers is another aspect of depletion faced by the household and community.

\section{Conclusion}

The preceding account discussed the subjection of Miyana prawn harvester households to multiple ongoing vectors of dispossession. Two of these vectors are due to contested access to the LRK natural resources: as a result of the closure of the LRK for wild ass conservation, and as a result of encroachment by salt corporations. The third important vector of dispossession of prawn harvesters is also ongoing, but a less visible, extractive relationship between capitalist accumulation within the prawn industry and fisher household modes of production. In this respect, the paper concurs with the argument of contemporary Marxists scholars that capitalist accumulation often entails ongoing dispossession of producers (such as peasant and fisher households) from the non-capitalist modes of production that sustain them.

The larger purpose of the paper however, has been to probe the gendered dynamics of production and social reproduction within the fisher households facing dispossession. The paper demonstrated that production within fisher households was contingent on the constitutive, necessary but invisible gendered labour of social reproduction. Viewed thus, 
dispossession is not only the structural violence of the appropriation of land and resources as delineated in Marxist scholarship, but also, importantly, the depletion of capacities due to gendered, differential exposure to the currents of structural violence, which are visible precisely in the realm of social reproduction. That is, if Marx "de-fetishized" commodities to show that they are, in the end, relationships, we could argue that dispossession is manifested through relationships of social reproduction that undergo depletion of capacities.

As the analysis here has shown, the consequence of dispossession was the depletion of fisher households' capacities for social reproduction: their biological reproductive capacity, the reproduction of their labour power, and their reproduction as a class all became increasingly unsustainable. Further, dispossession produced divergent livelihood strategies of survival or accumulation amongst Miyana households. The consequent class differentiated pathways intensified inequalities amongst the Miyana, and had gender specific consequences for women's socially reproductive labour.

Extrapolating from the case study, I offer the following generalized theses on the interconnection between dispossession and social reproduction: first, we need to consider dispossession, accumulation, production and social reproduction as inter-relationships within a system. Doing so is critical, as it makes visible aspects of these inter-relationships that may other-wise be hidden (such as socially reproductive labour, or debt-bondage relationships). Second, and related, I suggest that dispossession cannot simply be viewed as the extraeconomic coercive separation of producers from land or other productive resources. The theorization and empirical analysis of dispossession must consider the ways in which social reproduction is both constitutive of, and re-constituted by, relations of production. That is, it would be necessary to investigate whether and to what extent dispossession a) is contingent on the appropriation of socially reproductive labour, and b) results in the depletion (or enhancement) of capacities for social reproduction. Inevitably, this relationship will be context specific; it is possible in some contexts that dispossession does not entail appropriation of socially reproductive labour. In some contexts, dispossession may reduce social reproductive labour, however, the degree of depletion would depend on whether the productive labour is sufficient to sustain individuals and households.

Third, Rai et al.'s (2014) concept of depletion deepens our understanding particularly 
of the temporal dimensions of dispossession. Dispossession is typically conceived in terms of violent, grand structural moments of enclosure; however depletion also helps us see dispossession as an incremental, under-the-radar process of erosion of the capacity for social reproduction that is ongoing in the every-day lives of marginalized populations. I argue that the assessment of the intensity of depletion due to dispossession requires investigation of the degree of mitigation, replenishment or transformation available to individuals, households and communities within the circuits of production and social reproduction. Mitigation involves lessening of the harms due to depletion by re-distributing labour, the introduction of labour saving technology or buying in services (Rai et al. 2014: 98-99). We observed instances of mitigation for Miyana women: for some women mitigation occurred as their labour was re-distributed generationally (with children contributing to fish processing labour); however while mitigation may benefit these women as individuals, it does not reduce depletion within households. For women from households with Accumulative livelihood strategies, mitigation of depletion occurred through substitution of hired labour for women's unpaid labour; however, here the harm of depletion is transferred to another household. More profound reversal (rather than simply transfer) of depletion due to dispossession necessitates either rep previously where NGOs were considered a social resource, this resource could be viewed as form of replenishment within communities and reversal (to some degree) of the depletion engendered by dispossession. Similarly, in some of the case studies analysed by Levien (2015b), state provision of housing, electricity, water, health, education and other basic welfare services to displaced populations was an important replenishment of their capacity for social reproduction. In the case of the Miyana, the Gujarat state was completely absent in the provision of basic welfare services to support social reproduction at the temporary settlements. The failure of the state in its role of providing welfare as a compensatory mechanism to ensure social reproduction appears to validate Li's (2010: 79-80) pessimism regarding Karl Polanyi's prediction that the life-preserving, welfare interventions of the state would act as a homeostatic correction to the destructive tendencies of capitalist development. The third method of reversal of depletion is transformation that involves, first, the restructuring of gender relations so that both men and women are fully involved in social reproduction, and second, the recognition and valuation of social reproduction (Rai et al. 
2014: 99). While the current prospects for the former are not promising, particularly for Miyana women facing dispossession, social reproduction can and should certainly be recognised as a central axis of the analysis of dispossession. This paper hopes to have contributed to the latter agenda.

\section{Acknowledgements}

I gratefully acknowledge the invaluable support and contributions of the women of the Azaad Machimaar Fisherwomen's Co-operative and the staff of ANANDI Gujarat. Kandarp Talati offered excellent Gujarati translation assistance, and Isabella Ofner provided vital research assistance. Funding for the research was provided by the University of Melbourne Early Career Researcher grant.

\section{References}

Adnan S (2013) Land grabs and primitive accumulation in deltaic Bangladesh: Interactions between neoliberal globalization, state interventions, power relations, and peasant resistance. Journal of Peasant Studies 40(1):87-128

Adduci M (2009) Neoliberal wave rocks Chilika Lake, India: Conflict over intensive aquaculture from a class perspective. Journal of Agrarian Change 9(4):484-511

Bakker I and Gill S (eds) (2003) Power, Production, and Social Reproduction: Human In/security in the Global Political Economy. Basingstoke: Palgrave Macmillan Banerjee-Guha S (ed) (2010) Accumulation by Dispossession: Transformative Cities in the New Global Order. New Delhi: Sage

Baskaran R and Anderson J L (2005) Atlantic sea scallop management: An alternative rightsbased cooperative approach to resource sustainability. Marine Policy 29(4):357-369

Benjaminsen T A and Bryceson I (2012) Conservation, green/blue grabbing, and accumulation by dispossession in Tanzania. Journal of Peasant Studies 39(2):335-355 Bisht T C (2009) Development-induced displacement and women: The case of the Tehri Dam, India. Asia Pacific Journal of Anthropology 10(4):301-317 
Bokil M (2002) De-notified and nomadic tribes. Economic and Political Weekly 37(2):148154

Borras S, Hall R, Scoones I, White B and Wolford W (2011) Towards a better understanding of global land grabbing. Journal of Peasant Studies 38(2):209-216

Boserup E (1970) Woman's Role in Economic Development. London: Allen \& Unwin Breman J (1996) Footloose Labour: Working in India's Informal Economy. New York:

Cambridge University Press

Breman J, Guérin, I and Prakash A (eds) (2009) India's Unfree Workforce: Of Bondage Old and New. New Delhi: Oxford University Press

Campling L and Havice E (2014) The problem of property in industrial fisheries. Journal of Peasant Studies 41(5):707-727

Casolo J and Doshi S (2013) Domesticated dispossessions? Towards a transnational feminist geopolitics of development. Geopolitics 18(4):800-834

D’Souza D (1999) De-notified tribes: Still “criminal”? Economic and Political Weekly 34(51):3576-3578

Davis A (1996) Barbed wires and bandwagons: A comment on ITQ fisheries management. Reviews in Fish Biology and Fisheries 6(1):97-107

Deshingkar P and Farrington C (2009) Circular Migration and Multilocational Livelihood Strategies in Rural India. New Delhi: Oxford University Press

Edholm F, Harris O and Young K (1978) Conceptualising women. Critique of Anthropology 3(9/10):101-130

Elson D (1998) The economic, the political, and the domestic: Businesses, states, and households in the organisation of production. New Political Economy 3(2):189-208 Federici S (2004) Caliban and the Witch. New York: Autonomedia Federici S (2010) Women, witch-hunting, and enclosures in Africa today. Sozial Geschichte Online 3:10-27 http://duepublico.uni-duisburg-essen.de/servlets/DocumentServlet?id=22626 (last accessed 25 May 2017)

Glassman J (2006) Primitive accumulation, accumulation by dispossession, accumulation by "extra-economic" means. Progress in Human Geography 30(5):608-625

Goss J, Burch D and Rickson R (2000) Agri-food restructuring and Third World 
transnationals: Thailand, the CP Group, and the global shrimp industry. World Development 28(3):513-530

Government of India (2001) District Census Handbook: Rajkot District. Ahmedabad:

Directorate of Census Operations

Hartmann H I (1981) The unhappy marriage of Marxism and Feminism: Towards a more progressive union. In L Sargent (ed) Women and Revolution (pp1-42). London: Pluto Hartsock N (2006) Globalization and primitive accumulation: The contributions of David Harvey's dialectical Marxism. In N Castree and D Gregory (eds) David Harvey: A Critical Reader (pp167-190). Oxford: Blackwell

Harvey D (2003a) The New Imperialism. Oxford: Oxford University Press

Harvey D (2003b) The "new" imperialism: Accumulation by dispossession. In L Panitch and C Leys (eds) Socialist Register 2004: The New Imperial Challenge (pp63-87). London:

Merlin

Hauzer M, Dearden P and Murray G (2013) The fisherwomen of Ngazidja island, Comoros: Fisheries livelihoods, impacts, and implications for management. Fisheries Research 140:2835

Humphries J (1990) Enclosures, common rights, and women: The proletarianization of families in the late $18^{\text {th }}$ and early $19^{\text {th }}$ centuries. Journal of Economic History 50(1):17-42 Immanuel S and Syda Rao G (2009) The status of fisherwomen in Andhra Pradesh. Indian Journal of Gender Studies 16(3):411-423

Jalais A (2010) Braving crocodiles with Kali: Being a prawn seed collector and a modern woman in the $21^{\text {st }}$ century Sundarbans. Socio-Legal Review 6:1-23

Kabir G M S, Yew T S, Noh K M and Hook L S (2011) Assessing fishers' empowerment in inland openwater fisheries in Bangladesh. Ecological Economics 70(11):2114-2123 Keating C, Rasmussen C and Rishi P (2010) The rationality of empowerment: Microcredit, accumulation by dispossession, and the gendered economy. Signs 36(1):153-176 Kelly A B (2011) Conservation practice as primitive accumulation. Journal of Peasant Studies 38(4):683-701

Lebel L, Lebel P, Garden P, Giap D, Khrutmuang S and Nakayama S (2008) Places, chains, and plates: Governing transitions in the shrimp aquaculture production-consumption system. 
Globalizations 5(2):211-226

Levien M (2015a) From primitive accumulation to regimes of dispossession. Economic and Political Weekly 50(22):146-157

Levien M (2015b) Gender and land grabs in comparative perspective. In M Leach (ed) Gender Equality and Sustainable Development (pp105-132). New York: Routledge Li T M (2010) To make live or let die? rural dispossession and the protection of surplus populations. Antipode 41(s1):66-93

Li T M (2011) Centering labor in the land grab debate. Journal of Peasant Studies 38(2):281298

Luxemburg R (1968) The Accumulation of Capital. New York: Monthly Review Press Marks B (2012) The political economy of household commodity production in the Louisiana shrimp fishery. Journal of Agrarian Change 12(2/3):227-251

Marx K (1976 [1867]) Capital, Volume 1. London: Penguin

Mehta L and Srinivasan B (2000) Balancing Pains and Gains: A Perspective Paper on Gender and Large Dams. Cape Town: World Commission on Dams Secretariat Meertens D and Stoller R (2001) Facing destruction, rebuilding life: Gender and the internally displaced in Colombia. Latin American Perspectives 28(1):132-148 Mies M (1986) Patriarchy and Accumulation on a World Scale Women in the International Division of Labour. London: Zed

Molyneux M (1985) Mobilisation without emancipation: Women's interests and revolution in Nicaragua. Feminist Studies 11(2):227-254

Ngwenya B N, Mosepele K K and Magole L (2012) A case for gender equity in governance of the Okavango Delta fisheries in Botswana. Natural Resources Forum 36(2):109-122 Pearson G, Barratt C, Seeley J, Ssetaala A, Nabbagala G and Asiki G (2013) Making a livelihood at the fish-landing site: Exploring the pursuit of economic independence amongst Ugandan women. Journal of Eastern African Studies 7(4):751-765 Pradhan A (2011) Living on the Margins: Prawn Harvesters from Little Rann of Kutch (An Exploratory Study of Health Status). Mumbai: Centre for Health and Allied Themes Rai S M, Hoskyns C and Thomas D (2014) Depletion. International Feminist Journal of Politics 16(1):86-105 
Ravi Reddy D B (2012) 42 ${ }^{\text {nd }}$ Annual Report 2011-12. Cochin: Seafood Exporters Association of India

Salim S S and Geetha R (2013) Empowerment of fisherwomen in Kerala: An assessment. Indian Journal of Fisheries 60(3):73-80

Sharmin S and Khan N A (2011) Gender and development amongst a wetland community in Bangladesh: Views from the field. OIDA International Journal of Sustainable Development 3(4):11-21

Shobhana Warrier M V (2001) Women at work: Migrant women in fish processing industry. Economic and Political Weekly 36(37):3554-3562

Sinha S (2012) Transnationality and the Indian fishworkers' movement, 1960s-2000. Journal of Agrarian Change 12(2/3):364-389

Thukral E G (1996) Development, displacement, and rehabilitation: Locating gender.

Economic and Political Weekly 31(24):1500-1503

Veuthey S and Gerber J-F (2012) Accumulation by dispossession in coastal Ecuador: Shrimp farming, local resistance, and the gender structure of mobilizations. Global Environmental Change 22(3):611-622

White J and White B (2012) Gendered experiences of dispossession: oil palm expansion in a Dayak Hibun community in West Kalimantan. Journal of Peasant Studies 39(3/4):995-1016 Young K, Wolkowitz C and McCullagh R (1981) Of Marriage and the Market: Women's Subordination in International Perspective. London: CSE

This article is protected by copyright. All rights reserved. 


\section{University Library}

\section{- M M I N E R VA A gateway to Melbourne's research publications}

Minerva Access is the Institutional Repository of The University of Melbourne

Author/s:

Fernandez, B

Title:

Dispossession and the Depletion of Social Reproduction

Date:

2018-01-01

Citation:

Fernandez, B. (2018). Dispossession and the Depletion of Social Reproduction. ANTIPODE, 50 (1), pp.142-163. https://doi.org/10.1111/anti.12350.

Persistent Link:

http://hdl.handle.net/11343/293150 